\title{
Penerapan Pembelajaran Google Classroom Berbantuan Video Animasi terhadap Kemampuan Pemecahan Masalah Matematis Siswa SMP Negeri 5 Pekalongan
}

\author{
Fathimatuz Zahra An-Nawaf*, Sayyidatul Karimah, Syita Fatih 'Adna \\ Pendidikan Matematika, Universitas Pekalongan, Indonesia \\ *fathimaimaa@gmail.com
}

\begin{tabular}{|c|c|}
\hline Article Info & Abstract \\
\hline $\begin{array}{l}\text { Received } \\
21 \text { March } 2021\end{array}$ & $\begin{array}{l}\text { Distance learning aims to break the spread of Covid-19 in Indonesian. } \\
\text { Learning media is needed to deliver the material so that mathematical } \\
\text { problem solving (MPS) abilities are better. This study aims: (1) to } \\
\text { monitor the MPS abilities of students who used Google Classroom in }\end{array}$ \\
\hline $\begin{array}{l}\text { Revised } \\
03 \text { May } 2021\end{array}$ & $\begin{array}{l}\text { SMP Negeri } 5 \text { Pekalongan with the help of animated videos to } \\
\text { achieved KKM; (2) to found out the MPS abilities of students who used } \\
\text { Google Classroom with the help of animated videos, it was better than }\end{array}$ \\
\hline $\begin{array}{l}\text { Accepted } \\
27 \text { May } 2021\end{array}$ & $\begin{array}{l}\text { those who used WhatsApp Group (WAG) with assignments. This type } \\
\text { of research was a Posttest-Only Control Design. The research sample } \\
\text { was taken through the cluster random sampling technique from all }\end{array}$ \\
\hline Keywords & $\begin{array}{l}\text { students of eight graders in SMP Negeri } 5 \text { Pekalongan. Data } \\
\text { collection techniques were obtained through tests. Data analysis used } \\
\text { the proportion test to determining student learning completeness and }\end{array}$ \\
\hline Google Classroom & the mean difference test (test) to determine the difference in the mean \\
\hline Animated Videos & between the two groups. The results of this study: (1) students' MPS \\
\hline Mathematical & abilities used Google Classroom with the help of animated videos to \\
\hline Problem Solving & achieved KKM; (2) students' MPS abilities used Google Classroom \\
\hline Ability & $\begin{array}{l}\text { with the help of animated videos, it was better than those who used } \\
\text { WAG with assignments. }\end{array}$ \\
\hline
\end{tabular}

How to Cite:

An-Nawaf, F. Z., Karimah, S., \& 'Adna, S. F. (2021). Penerapan Pembelajaran Google

Classroom Berbantuan Video Animasi Terhadap Kemampuan Pemecahan Masalah

Matematis Siswa SMP Negeri 5 Pekalongan. Journal of Instructional Mathematics, $2(1), 36-43$.

\section{PENDAHULUAN}

Sekitar bulan Maret tahun 2020 Indonesia dilanda wabah virus Covid-19 yang kabarnya bersumber dari negara China. Maka dari itu untuk mencegah penyebaran virus Covid-19 dalam dunia Pendidikan di Indonesia, Menteri Pendidikan dan Kebudayaan RI, Nadiem Anwar Makarim mengambil kebijakan pembelajaran selama pandemi. Salah satu kebijakan pelaksanaan Pendidikan dalam masa darurat ini yaitu merubah cara belajar mengajar melalui pembelajaran daring (pembelajaran jarak jauh menggunakan fasilitas online). Pembelajaran daring dilakukan dengan tujuan agar proses pembelajaran siswa dapat berlangsung meskipun dilaksanakan dalam keadaan pandemi seperti ini.

Begitu pula pembelajaran yang dilakukan di SMP Negeri 5 Pekalongan, SMP Negeri 5 Pekalongan menetapkan proses pembelajaran dilakukan secara daring. Pembelajaran daring tersebut dilakukan melalui WAG dan Google Classroom. Pembelajaran melalui Google Classroom dan WAG yang dilakukan oleh guru, 
hanya dengan pemberian materi singkat serta contoh soal, dilanjutkan dengan pemberian latihan soal. Kemudian siswa diberi waktu untuk mengerjakan soal soal dan memahami materi selama 2 minggu. Proses pembelajaran seperti ini menyulitkan siswa, karena tidak ada konfirmasi ulang dari guru mengenai materi tersebut.

Berdasarkan hasil wawancara dengan guru mata pelajaran matematika di kelas VIII SMP Negeri 5 Pekalongan, terdapat permasalahan yaitu kemampuan pemecahan masalah matematis siswa kurang sesuai dengan yang diharapkan oleh guru. Hal tersebut dituturkan oleh salah seorang guru yang mengampu mata pelajaran matematika. Ketika siswa dihadapkan pada soal pemecahan masalah, siswa mengetahui rumus apa yang akan digunakan tetapi kesulitan dalam mengidentifikasi unsur-unsur yang diketahui dan menerapkannya dalam rumus sebagai penyelesaian masalah. Dengan demikian kemampuan pemecahan masalah matematis siswa di SMP Negeri 5 Pekalongan dikatakan masih rendah. Suherman dkk. (2009: 89) menyatakan bahwa dalam kurikulum matematika sekolah, tujuan diberikannya matematika antara lain agar siswa mampu menghadapi perubahan keadaan di dunia yang selalu berkembang, melalui latihan bertindak atas dasar pemikiran secara logis, rasional, kritis, cermat, jujur dan efektif. Selain itu, National Council of Teachers of Mathematics (NCTM, 2000:52) juga mengungkapkan bahwa pemecahan masalah tidak hanya merupakan tujuan dari pembelajaran matematika, tetapi juga merupakan alat utama untuk melakukan belajar. Selain itu Suherman dkk (2009:7) juga menyatakan bahwa kemampuan pemecahan masalah matematis adalah kemampuan mencari cara dan metode untuk menyelesaikan masalah dalam matematika melalui kegiatan mengamati, memahami, mencoba, menduga dan menemukan serta meninjau kembali.

Melalui pengalaman secara terus-menerus, sedikit demi sedikit siswa akan berkembang secara utuh, baik pada aspek kognitif, afektif dan psikomotorik. Dengan demikian suatu pertanyaan atau soal merupakan masalah bagi siswa, apabila siswa tersebut tidak mempunyai cara tertentu yang dapat dipergunakan untuk menyelesaikan jawaban atas pertanyaan itu. Akan tetapi, siswa memiliki keinginan untuk menyelesaikan masalah tersebut dengan cara yang telah diketahui sebelumnya. Menurut Lestari \& Yudhanegara (2017: 85) indikator kemampuan pemecahan masalah matematis adalah sebagai berikut: (a) mengidentifikasi unsurunsur yang diketahui, ditanyakan, dan kecukupan unsur yang diperlukan; (b) merumuskan masalah matematis atau menyusun model matematika; (c) menerapkan strategi untuk menyelesaikan masalah; (d) menjelaskan atau menginterpretasikan hasil penyelesaian masalah.

Kemampuan pemecahan masalah matematis siswa dapat dipengaruhi oleh model pembelajaran dan media pembelajaran yang digunakan oleh guru. Untuk menciptakan suasana belajar yang menyenangkan serta memudahkah siswa, guru perlu merancang perencanaan pembelajaran, pemilihan pembelajaran yang bervariasi, menyediakan sumber belajar yang variatif, dan mampu memilih media pembelajaran yang memungkinkan siswa mudah dalam menyerap informasi serta mampu menumbuhkan motivasi belajar siswa sehingga dalam kegiatan pembelajaran siswa memiliki peran aktif. Model pembelajaran memiliki peran penting dalam proses pembelajaran. Untuk mendapatkan hasil yang maksimal dalam proses pembelajaran tidak hanya sekedar mengirimkan file materi dan latihan soal saja saat pembelajaran jarak jauh tetapi perlu adanya media 
pembelajaran yang membantu proses pemahaman sisiwa. Menurut Hamzah, Ali \& Muhlisrarini (2014: 95) menyatakan bahwa media merupakan suatu saluran untuk komunikasi suatu perantara yang membawa informasi dari pengirim kepada penerima imformasi, informasi itu multimakna dilihat secara terbatas atau luas.

Salah satu media yang dapat digunakan untuk memberikan kemampuan pemecahan masalah matematis siswa dalam mempelajari materi matematika adalah media pembelajaran video animasi. Media pembelajaran yang disajikan dengan video animasi ini, dapat melibatkan siswa dalam berpikir dan melakukan aktivitas belajar matematika dengan lebih efektif, lebih cepat, dan lebih mendalam, dari pada sekedar pemberian file materi saja. Pembelajaran melalui Google Classroom berbantuan video animasi ini sangat memudahkan siswa untuk memahami materi yang diberikan oleh guru. Siswa dapat memutar ulang penjelasan materi yang ada di dalam video tersebut sesuai dengan sejauh mana pemahaman siswa. Dengan demikian, kemampuan pemecahan masalah matematis siswa bisa lebih baik.

Pada penelitian ini pembelajaran dilakukan melalui Google Classroom. Google Classroom adalah layanan web gratis yang dikembangkan oleh Google. Pengajar dan siswa yang ingin menggunakan Google Classroom wajib memiliki akun Google Classroom terlebih dahulu agar saling terhubung. Proses pembelajaran melalui Google Classroom diharapkan dapat menjadikan pembelajaran lebih efektif dan efisien. Tujuan utama Google Classroom adalah untuk merampingkan proses berbagi file antara guru dan siswa. Google Classroom tentu memiliki kekurangan dan kelebihan. Menurut Iftakhar (2016) menyatakan bahwa kelebihan Google Classroom diantaranya easy to use, saves time, cloud-based, free, flexible, free, mobile-friendly. Selain kelebihan, tentunya Google Classroom juga memiliki kekurangan. Kekurangan Google Classroom diantaranya: Google Classroom yang berbasis web mengharuskan siswa dan guru untuk terkoneksi dengan internet, pembelajaran berupa individual sehingga mengurangi pembelajaran sosial peserta didik, serta menumbuhkan spesifikasi hardware, software, dan jaringan internet yang tinggi (Ayuningrum, Kusuma \& Ripki, 2020).

Adapun langkah-langkah pembelajaran Google Classroom berbantuan video animasi: (a) guru menginstruksikan siswa untuk masuk ke Google Classroom melalui WAG kelas; (b) guru memberikan salam dan memotivasi pentingnya belajar di rumah; (c) guru mengirimkan video animasi yang telah diberikan melalui Google Classroom (link untuk akses ke YouTube); (d) guru memberikan pacingan pertanyaan dikolom komentar Google Classroom untuk melakukan diskusi dengan siswa setelah selesai menonton video animasi yang telah diberikan; (e) guru melakukan evaluasi pembelajaran dengan memberikan soal-soal latihan.

Peneliti mengambil pembelajaran melalui Google Classroom dengan berbantuan video animasi dikarenakan video animasi sebagai alat bantu yang membawa informasi dan pengetahuan dalam interaksi antara guru dengan siswa pada saat pembelajaran berlangsung. Media pembelajaran dapat memudahkan guru dalam menyampaikan materi serta memudahkan siswa dalam memahami materi yang berikan oleh guru, karena materi disajikan melalui audio visual dengan berbagai fitur yang menarik serta materi di sampaikan secara detail. Selain itu, penyampaian materi memperhatikan pengetahuan setiap siswa dalam menguasai sehingga pembelajaran menjadi lebih menarik dan tidak membosankan. Hal ini sejalan dengan penelitian yang dilakukan oleh Sudiarta \& Sadra (2016) memberikan kesimpulan bahwa penggunaan model pembelajaran Blended 
Learning berbasis video animasi dapat meningkatkan kemampuan pemahaman konsep siswa.

Tujuan dari penelitian ini adalah: (1) Untuk mengetahi apakah kemampuan pemecahan masalah matematis siswa yang menggunakan Google Classroom di Negeri 5 Pekalongan berbantuan video animasi dapat mencapai KKM. (2) Untuk mengetahui apakah kemampuan pemecahan masalah matematis siswa di SMP Negeri 5 Pekalongan yang menggunakan Google Classroom berbantuan video animasi lebih baik daripada kemampuan pemecahan masalah matematis siswa di SMP N 5 Pekalongan yang menggunakan WAG dengan penugasan.

\section{METODE PENELITIAN}

Penelitian ini dilakukan di SMP Negeri 5 Pekalongan tahun ajaran 2020/2021. Penelitian ini termasuk penelitian kuantitatif dengan metode eksperimen. Desain yang digunakan dalam penelitian ini yaitu Posttest-Only Control Design. Populasi dari penelitian ini adalah seluruh siswa kelas VIII di SMP Negeri 5 Pekalongan.

Pengambilan sampel dalam penelitian ini menggunakan teknik Cluster Random Sampling. Cara menentukan sampel dengan teknik Cluster Random Sampling yaitu dengan memilih kelas secara acak tanpa memperhatikan strata yang ada dalam populasi itu untuk dijadikan sampel penelitian. Teknik sampling dilakukan bila anggota populasi dianggap homogen. Sampel yang diambil yaitu kelas VIII D sebagai kelas eksperimen, kelas VIII E sebagai kelas kontrol dan kelas VIII F sebagai kelas uji coba. kelas VIII D sebagai kelas eksperimen yang diberikan perlakuan dengan diajar menggunakan pembelajaran Google Classroom berbantuan Video Animasi dan kelas VIII E sebagai kelas kontrol yang diajar menggunakan WAG berbasis penugasan. Teknik pengumpulan data yang digunakan adalah tes kemampuan pemecahan masalah matematis siswa. Tes ini digunakan untuk mengumpulkan data kemampuan pemecahan masalah matematis siswa.

Sebelum dilakukan penelitian, terlebih dahulu meminta nilai PTS (Penilaian Tengah Semester) kelas VIII tahun pelajaran 2020/2021 untuk dilakukan analisis data awal. Analisis data awal yang dilakukan meliputi uji normalitas, uji homogenitas, dan uji kesamaan rerata. Dari hasil analisis yang sudah dilakukan, menunjukkan hasil bahwa kelas eksperimen dan kelas kontrol berasal dari populasi yang berdistribusi normal, memiliki variansi yang sama (homogen), dan memiliki rerata yang sama. Lalu data akhir diperoleh setelah adanya perlakuan melalui tes. Analisis data akhir yang dilakukan meliputi uji normalitas, uji homogenitas, uji proporsi, dan uji-t.

\section{Analisis Data Awal}

\section{HASIL DAN PEMBAHASAN}

Sebelum dilaksanakan penelitian, dilakukan analisis data awal dengan uji normalitas, uji homogenitas, dan uji kesamaan rerata. Data yang digunakan adalah nilai PTS (Penilaian Tengah Semester) VIII tahun ajaran 2020/2021. 


\section{Uji Normalitas}

Tabel 1. Hasil Uji Normalitas Data Awal

\begin{tabular}{lcccc}
\hline \multicolumn{1}{c}{ Kelas } & $L_{\text {hitung }}$ & $L_{\text {tabel }}$ & Keputusan & Keterangan \\
\hline Eksperimen & 0,0766 & 0,1610 & $L_{\text {hitung }} \leq L_{\text {tabel }}$ & $H_{0}$ diterima \\
Kontrol & 0,0953 & 0,1610 & $L_{\text {hitung }} \leq L_{\text {tabel }}$ & $H_{0}$ diterima \\
\hline
\end{tabular}

Berdasarkan Tabel 1 bahwa kelas ekeprimen bahwa pada kelas eksperimen nilai $L_{\text {hitung }}$ sebesar 0,0766 dan nilai $L_{\text {tabel }}$ sebesar 0,1610 sehingga $L_{\text {hitung }} \leq L_{\text {tabel }}$. Akibatnya $H_{0}$ diterima tau sampel berasal dari populasi berdistribusi normal. Sementara itu, pada kelas kontrol nilai $L_{\text {hitung }}$ sebesar 0,0953 dan nilai $L_{\text {tabel }}$ sebesar 0,1610 sehingga $L_{\text {hitung }} \leq L_{\text {tabel }}$. Akibatnya $H_{0}$ diterima atau sampel berasal dari populasi berdistribusi normal.

\section{Uji Homogenitas}

Tabel 2. Hasil Uji Homogenitas Data Awal

\begin{tabular}{ccccc}
\hline Kelas & $F_{\text {hitung }}$ & $F_{\text {tabel }}$ & Keputusan & Keterangan \\
\hline Eksperimen \& Kontrol & 1,5462 & 1,9048 & $F_{\text {hitung }}<F_{\text {tabel }}$ & $H_{0}$ diterima \\
\hline
\end{tabular}

Berdasarkan Tabel 2 terlihat bahwa nilai $F_{\text {hitung }}$ sebesar 1,5462 dan nilai $F_{\text {tabel }}$ sebesar 1,9048 sehingga $F_{\text {hitung }}<F_{\text {tabel. }}$. Akibatnya $H_{0}$ diterima yang artinya Tidak ada perbedaan nilai varians antara kelas eksperimen dan kelas kontrol atau populasi berasal dari variansi homogen.

\section{Uji Kesamaan Rerata}

Tabel 3. Hasil Uji Kesamaan Rerata Data Awal

\begin{tabular}{ccccc}
\hline Kelas & $t_{\text {hitung }}$ & $t_{\text {tabel }}$ & Keputusan & Keterangan \\
\hline $\begin{array}{c}\text { Eksperimen \& } \\
\text { Kontrol }\end{array}$ & 0,135 & 2,0048 & $-t_{\text {tabel }}<t_{\text {obs }}<t_{\text {tabel }}$ & $H_{0}$ diterima \\
\hline
\end{tabular}

Berdasarkan Tabel 3 terlihat bahwa nilai $t_{\mathrm{obs}}$ sebesar 0,135 dan nilai $t_{\text {tabel }}$ sebesar 2,0048 sehingga $-t_{\text {tabel }}<t_{\text {obs }}<t_{\text {tabel }}$. Akibatnya $H_{0}$ diterima yang berarti nilai ratarata kemampuan pemecahan masalah matematis siswa kelas eksperimen sama dengan nilai rata-rata siswa kelas kontrol.

\section{Analisis Data Akhir}

Analisis data akhir dilakukan uji normalitas, uji homogenitas, dan uji efektifitas (uji proporsi dan uji-t).

\section{Uji Normalitas}

Tabel 4. Hasil Uji Normalitas Data Akhir

\begin{tabular}{ccccc}
\hline Kelas & $L_{\text {hitung }}$ & $L_{\text {tabel }}$ & Keputusan & Keterangan \\
\hline Eksperimen & 0,0763 & 0,1610 & $L_{\text {hitung }} \leq L_{\text {tabel }}$ & $H_{0}$ diterima \\
Kontrol & 0,0834 & 0,1610 & $L_{\text {hitung }} \leq L_{\text {tabel }}$ & $H_{0}$ diterima \\
\hline
\end{tabular}

Berdasarkan Tabel 4 terlihat bahwa pada kelas eksperimen nilai $L_{\text {hitung }}$ sebesar 0,0763 dan nilai $L_{\text {tabel }}$ sebesar 0,1610 sehingga $L_{\text {hitung }} \leq L_{\text {tabel }}$. Akibatnya $H_{0}$ diterima atau sampel berasal dari populasi berdistribusi normal. Sementara itu, pada kelas 
kontrol nilai $L_{\text {hitung }}$ sebesar 0,834 dan nilai $L_{\text {tabel }}$ sebesar 0,1610 sehingga $L_{\text {hitung }} \leq L_{\text {tabel. }}$. Akibatnya $H_{0}$ diterima atau sampel berasal dari populasi berdistribusi normal.

\section{Uji Homogenitas}

Tabel 5. Hasil Uji Homogenitas Data Awal

\begin{tabular}{ccccc}
\hline Kelas & $F_{\text {hitung }}$ & $F_{\text {tabel }}$ & Keputusan & Keterangan \\
\hline $\begin{array}{c}\text { Eksperimen } \& \\
\text { Kontrol }\end{array}$ & 0,572 & 1,9048 & $F_{\text {hitung }}<F_{\text {tabel }}$ & $H_{0}$ diterima \\
\hline
\end{tabular}

Berdasarkan Tabel 5 terlihat bahwa nilai $F_{\text {hitung }}$ sebesar 0,572 dan nilai $F_{\text {tabel }}$ sebesar 1,9048 sehingga $F_{\text {hitung }}<F_{\text {tabel. }}$. Akibatnya $H_{0}$ diterima yang artinya tidak ada perbedaan nilai varians antara kelas eksperimen dan kelas kontrol atau populasi berasal dari variansi homogen.

\section{Uji Efektivitas}

Uji Proporsi

Uji proporsi data akhir digunakan untuk mengetahui ketuntasan kelompok kelas eksperimen yang telah mencapai KKM yaitu 70 sebesar $75 \%$. Uji proporsi dalam penelitian ini menggunakan uji pihak kanan dengan menggunkan rumus uji $\mathrm{Z}$.

\begin{tabular}{ccccc}
\multicolumn{5}{c}{ Tabel 6. Hasil Uji Proporsi } \\
\hline Kelas & $Z_{\text {hitung }}$ & $Z_{\text {tabel }}$ & Keputusan & Keterangan \\
\hline Eksperimen & 1,75 & 1,640 & $Z_{\text {hitung }}>Z_{\text {tabel }}$ & $H_{0}$ ditolak \\
\hline
\end{tabular}

Berdasarkan Tabel 6 terlihat bahwa pada kelas eksperimen nilai $Z_{\text {hitung }}$ sebesar 1,75 dan nilai $Z_{\text {tabel }}$ sebesar 1,6450 sehingga $Z_{\text {hitung }}>Z_{\text {tabel. }}$. Akibatnya $H_{0}$ ditolak yang artinya Proporsi siswa diajar menggunakan Google Classroom dengan menggunakan video animasi mendapat nilai $\geq 70$ lebih dari $75 \%$.

\section{Uji Beda Rerata}

Uji beda rerata data akhir digunakan untuk mengetahui keefektifan pembelajaran Google Classroom berbantuan video animasi. Uji beda rerata dalam penelitian ini menggunakan uji pihak kanan dengan menggunakan rumus uji-t.

Tabel 7. Hasil Uji Homogenitas Data Awal

\begin{tabular}{ccccc}
\hline Kelas & $t_{\text {hitung }}$ & $t_{\text {tabel }}$ & Keputusan & Keterangan \\
\hline Eksperimen \& Kontrol & 2,44 & 2,0048 & $t_{\text {hitung }}>t_{\text {tabel }}$ & $H_{0}$ ditolak \\
\hline
\end{tabular}

Berdasarkan Tabel 7, terlihat bahwa nilai $t_{\text {obs }}$ sebesar 2,44 dan nilai $t_{\text {tabel }}$ sebesar 2,0048 sehingga $t_{\text {obs }}>t_{\text {tabel }}$. Akibatnya $H_{0}$ ditolak atau Pemecahan masalah matematis siwa yang diajarkan melalui Google Classroom dengan berbantuan video animasi lebih baik dari pada pemecahan masalah matematis siswa yang diajarkan menggunakan Google Classroom dengan penugasan.

Siregar \& Nara (2014: 30) mengemukakan bahwa teori Jean Piaget lebih menekankan pada proses belajar dari pada hasil belajar. Bagi penganut aliran kontruktivisme, belajar tidak sekedar melibatkan hubungan antara stimulus dan 
respon, lebih dari itu belajar adalah melibatkan proses berpikir yang sangat kompleks. Teori belajar Jean Piaget digunakan karena teori ini berhubungan dengan aspek kognitif yang menekan siswa berfikir secara logis dalam memecahkan konsep-konsep matematika. Sehingga dari proses tesrsebut siswa terbiasa untuk berpikir dan menyelesaikan permasalahan matematika siswa dan berdampak pada jumlah siswa yang mencapai Kriteria Ketuntasan Minimal (KKM).

Pembelajaran menggunakan Google Classroom berbantuan video animasi dapat meningkatkan kemampuan pemecahan masalah matematis siswa lebih baik dibandingkan dengan pembelajaran WAG berbasis penugasan. Hal ini dikarenakan penggunaan media pembelajaran yaitu video animasi dapat memudahkan siswa dalam memahami materi yang disampaikan oleh guru meskipun disampaikan jarak jauh. Selain itu, siswa dapat memutar ulang video tersebut sesuai dengan pemahaman masing-masing siswa. Dengan demikian, pembelajaran menjadi lebih menarik dan mampu menumbuhkan semangat belajar dalam diri siswa.

Berdasarkan hasil uji proporsi dan uji beda rerata di atas, dapat disimpulkan bahwa penerapan pembelajaran E-Learning menggunakan Google Classroom berbantuan Video Animasi efektif terhadap pemecahan masalah matematis siswa. Seperti yang dijelaskan oleh Hamalik (dalam Handhika, 2012; Indriyani, 2019; Nurmadiah, 2016; Sakti, Puspasari \& Risdianto, 2012) bahwa pemakaian media pembelajaran dalam proses pembelajaran dapat membangkitkan motivasi dan rangsangan kegiatan belajar, dan bahkan membawa pengaruh-pengaruh psikologis terhadap siswa. Dengan demikian, pembelajaran Google Classroom berbantuan video animasi mampu menghasilkan kemampuan pemecahan masalah matematis siswa yang baik.

\section{KESIMPULAN}

Berdasarkan hasil penelitian dan pembahasan yang telah diuraikan, maka dapat disimpulkan sebagai berikut: (1) Kemampuan pemecahan masalah matematis siswa yang menggunakan Google Classroom di SMP Negeri 5 Pekalongan berbantuan video animasi dapat mencapai KKM; (2) Kemampuan pemecahan masalah matematis siswa di SMP Negeri 5 Pekalongan yang menggunakan Google Classroom berbantuan video animasi lebih baik daripada kemampuan pemecahan masalah matematis siswa di SMP Negeri 5 Pekalongan yang menggunakan WAG dengan penugasan.

\section{REFERENSI}

Ayuningrum, L., Kusuma, A. P., \& Ripki, A. J. (2020). Eksperimentasi Pembelajaran E-Learning melalui Google Classroom dan Pembelajaran Langsung pada Materi Segitiga terhadap Hasil Belajar ditinjau dari Kemampuan Penalaran Matematis Siswa. In Prosiding Seminar Nasional Pendidikan STKIP Kusuma Negara II (pp. 1-7).

Hamzah, A., \& Muhlisrarini. (2014). Perencanaan dan Strategi Pembelajaran Matematika. Jakarta : PT. Raja Grafindo Persada.

Handhika, J. (2012). Efektivitas media pembelajaran IM3 ditinjau dari motivasi belajar. Jurnal Pendidikan IPA Indonesia, 1(2), 109-114. 
Iftakhar, S. (2016). Google classroom: what works and how. Journal of Education and Social Sciences, 3(1), 12-18.

Indriyani, L. (2019). Pemanfaatan media pembelajaran dalam proses belajar untuk meningkatkan kemampuan berpikir kognitif siswa. In Prosiding Seminar Nasional Pendidikan FKIP (pp. 17-26).

Lestari, K. E., \& Yudhanegara, M. R. (2017). Penelitian Pendidikan Matematika. Bandung: Refika Aditama.

NCTM. (2000). Principles And Standart For School Mathematics. Virginia : Reston, VA: NCTM.

Nurmadiah, N. (2016). Media Pendidikan. Al-Afkar: Jurnal Keislaman \& Peradaban, 5(1), 43-62.

Sakti, I., Puspasari, Y. M., \& Risdianto, E. (2012). Pengaruh model pembelajaran langsung (Direct Instruction) melalui media animasi berbasis macromedia flash terhadap minat belajar dan pemahaman konsep fisika siswa di SMA Plus Negeri 7 Kota Bengkulu. Exacta, 10(1), 1-10.

Siregar, E., \& Nara, H. (2014). Teori Belajar dan Pembelajaran. Bogor: Ghalia Indonesia.

Sudiarta, I. G. P., \& Sadra, I. W. (2016). Pengaruh model blended learning berbantuan video animasi terhadap kemampuan pemecahan masalah dan pemahaman konsep siswa. Jurnal Pendidikan dan pengajaran, 49(2), 48-58.

Suherman, E., dkk. (2009). Strategi Pembelajaran Matematika Kontemporer. Bandung: Alfabeta. 